\title{
Political and Social Reflection of Post-Colonial Kazakhstan in Translations of American Literature (on the Basis of the Works by Jusupbek Aimautuly and Jack London)
}

\author{
Karlygash Aubakirova ${ }^{1}$ \\ ${ }^{1}$ L. Gumilyov Eurasian National University, Astana, Kazakhstan \\ Correspondence: Karlygash Aubakirova, L. Gumilyov Eurasian National University, 2 Satpayev Street, Astana, \\ 010008, Kazakhstan. E-mail: aubakirovakarlygash@gmail.com
}

Received: October 6, 2015 Accepted: October 24, 2015 Online Published: October 28, 2015

doi:10.5539/ass.v11n27p8 URL: http://dx.doi.org/10.5539/ass.v11n27p8

\begin{abstract}
This article analyzes historical and political views in the translations of the Kazakh writer Jusupbek Aimautuly from Jack London's works. It was the first time when Jack London who is the representative of American literary was translated into the Kazakh language and this work analyzes its reaction on Kazakh literature. Jusupbek Aimautuly was determined as a wise and skillful writer and a good politician at the beginning of XX century according to his translations. There was investigated Jack London's unknown to him spiritual influence to the Kazakh people by quantitative and qualitative research methods. The translations described sadness, torment and unhappiness of the Kazakh people that was under the invasion policy and genocide of the Soviet Union. It was determined that these translations avoided censorship and tragedy of Kazakh steppe and could find their publicity. It was found out that Aimautuly could represent his thoughts, his purposes and wishes to his nation; he talked about preservation of the nation, importance of unity and power of knowledge through the translation. At the same time, he saved all the rules of translation theory and he showed his skills in order to represent Jack London's prowess to the mind of the Kazakh people.
\end{abstract}

Keywords: the national idea, Alashorda, repression, censorship, translation, postcolonial literature

\section{Introduction}

The beginning of the XX century was one of the most crucial stage in the history for the Kazakh people. Rightful heir of the Golden Horde Khanate in Central Asia, Saks generation by Herodotus records - the Kazakh people were under colony of the Soviet Union because of different historical events and it has known during more than hundred years. Kazakh and Russian relationship worsened over time because of different religion, language, traditions and customs consciousness of life. The pressure for the Kazakh people was the cause of unity intelligentsia and opposition to the policy of colonization and their strong desire for freedom. The Kazakh intelligentsia founded "Alashorda" party that aimed at the country's freedom in 1917. Alikhan Bokeikhanov who was descendant of Genghis Khan was a leader of "Alashorda" that fought hard for the Kazakh people's freedom. Because of invasion, humiliation and violence of the Soviet Union to the Kazakh people there appeared a threat for preservation the Kazakhs as a nation. Settling the best places by Russian farmers and the genocide against the Kazakhs were the cause of difficulties of political situation for representatives of Alashorda and the authorities of the Soviet Union (Kendirbaeva, 1999).

However, Russian power did not refuse from their actions such as strict rules and violence to Kazakhs. They grabbed the land of nomads and stole their cattle; as a result they created unprecedented hand-made famine in the Kazakh field. By the beginning of the 20th century economic and social problems caused by the Russian colonization of Kazakhstan had reached a critical point. People who were against Russia's sovereignty and law were deported and arrested. It was a cause to develop actions of underground policy connected with religion and language. Kazakh scholar of the history of Kazakhstan M.Koigeldi says: "... the genocide in Kazakhstan led to hunger and aimless moving, of the Kazakh people. Kazakh steppe was full of sobbing mothers, crying children and smell of the death. All these were the result of the Bolsheviks' experiment in the Kazakh place" (Koigeldiyev \& Omarbekov, 1993).

During these difficult times, one of the important representative of the Kazakh intelligentsia who defended the 
interests of the nation's, a member of the Alashorda Party (founded in 1917) writer, essayist, critic, founder of psychology in Kazakh and translator, Jusupbek Aimautuly created an invaluable legacy to posterity. He was the first who translated the American literature into the Kazakh language. He died for the independence of the Kazakhs. By translating world classical works, he wanted to avoid Russian censorship and to represent his views to his nation, being the best in translating and using such kind of techniques. Representative of Kazakh literature G.Musrepov said: "I have not met such an educated, gifted, person as Jusupbek Aimautuly. I know Jusupbek as a great musician, scientist, a talented founder of the artistic criticism" (Anyz Adam, 2014). Outstanding person of the Kazakh prose, writer Beimbet Mailin says "I have never seen such a skillful writer as Jusupbek Aimautuly"' (Anyz Adam, 2014). When there was any conversation about Jusupbek Aimautuly, the whole Kazakh intelligentsia mentioned his knowledge and talent, hard work and love for the people, for his nation. Whatever he did, everything was for the nation. Jusupbek Aimautuly described the situation in the Kazakh steppe through his translations and he tried to show his thoughts about the Kazakh people. Aimautuly chose the high-quality works in order to reflect his opinion through wonderful translations. Jusupbek Aimautuly translated Jack London's "The strength of the strong" and "Unparalleled invasion" which were popular in the Russian translation.

The most important question of the research is why Jusupbek Aimautuly translated Jack London's stories? How did the works of the representative of American literature, Jack London, influenced in unknown way the Kazakh's spirit? What was the main purpose and idea of translations and how did he use them?

\section{Research Methods}

A variety of research methods were used in this article, which gave an objective picture of the historical and political conditions of Kazakhstan over 20-30 years in the 20th century. These methods elaborate on the main theme: translation of American works into the Kazakh language, and the government's attitude towards the intelligentsia of that time. The main results of the study were obtained through research on and analysis of rare materials from archival documents and manuscript collections. More than 200 archival documents were collected during expeditions to archives and libraries of Kazakhstan, Russia, and China. The main documents were analyzed in Russia in November 2013 in the State Library in Moscow, in the library of Minzu University in Beijing of China in October 2014, and in Kazakhstan's Semey archives. Rare manuscript collections were investigated in the National Library of Kazakhstan in Almaty. At the same time, some data was collected by conducting 5 interviews with experts of the Alash Research Institute. Along with biographical, historical, cultural, content and comparative analysis of the research methods, associated textual analyses were used. Having investigated more than 30 of Aimautuly's works, the impressive results of the research revealed more than 300 digital units (J. Aimautuly's Collection of Works, 2013).

\section{Results and Discussion}

\subsection{The Historical and Political Context}

It is impossible to describe the adversity of consequences of artificial hunger in Kazakhstan. There are a lot of stories about hunger by old people. Academicians have been gathering data and doing survey, but this topic is not fully studied today. As during the Soviet Union period it was prohibited, and now it is not question to discuss because of international peace rules. There are a lot of stories of old people who were deprived of their brothers and sisters during hunger. One of such story is described by $\mathrm{X}$ matron:

"We hugged our children, when we went to bed, because there were a lot of people who ate others. I was deprived of old father in such a way. Spring 1932... We were glad to go through winter. My father went for a walk. Spring was cold and snow did not melt... Neighbors said he was outside... I still don't know where he went to..." Consequences of hunger took away humanity of people.

The document below proves the situations of cannibalism. 


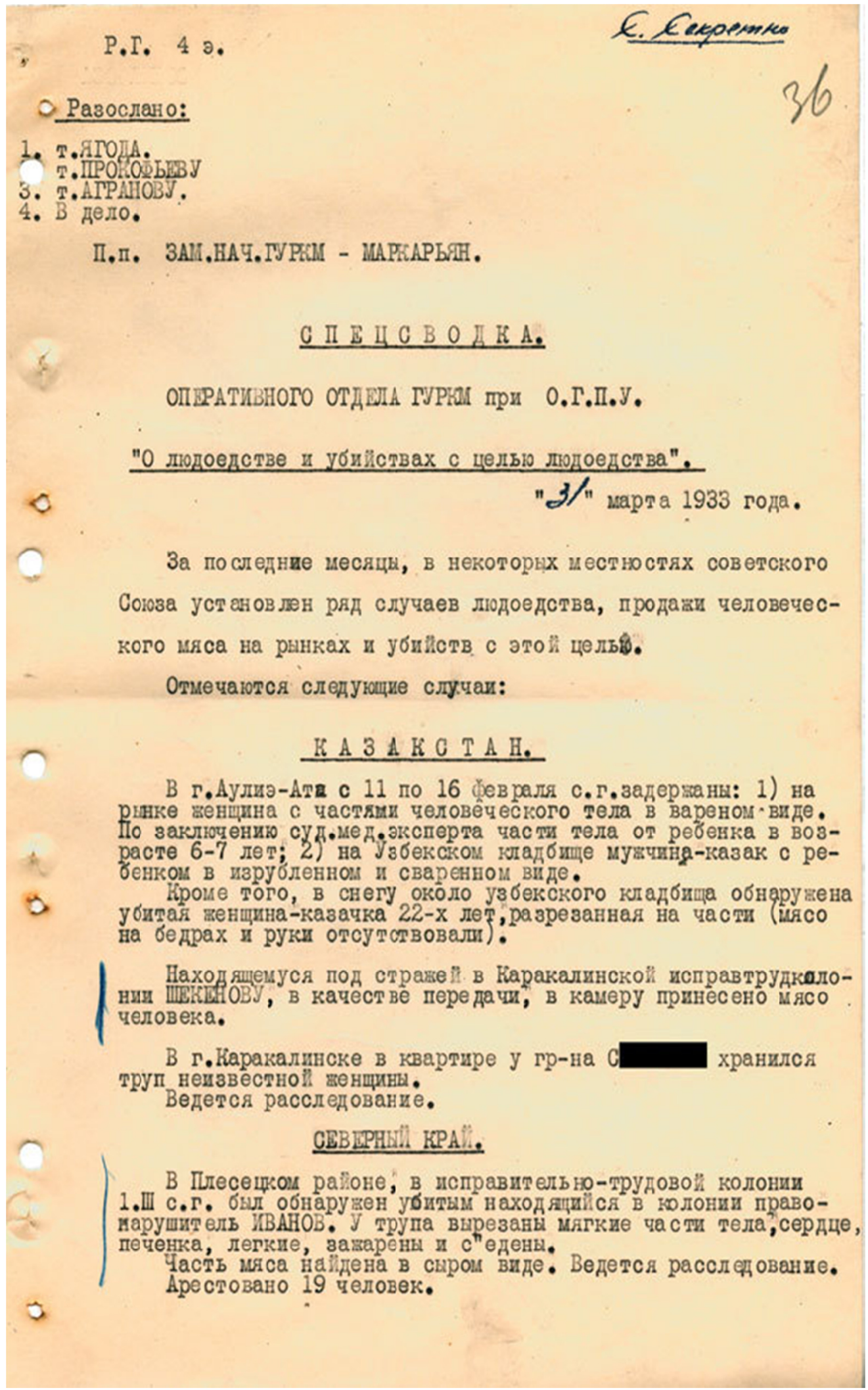

Note. From Alzhir - Akmola Camp of Wives of Traitors. 


\section{Send out: \\ 1. Yagoda \\ 2. Prokoveva \\ 3. Agranova \\ 4. In dosier}

Deputy of Head of WPCA - Makaryan

SPECIAL SUMMARY

WPCA OPERATIVE BRANCH BY USPA

"About cannibalism and murders with the purpose of cannibalism"

31 March 1933

During the last month there were found out a set of incidents of cannibalisms, selling human's meat in the market and murders designed to it in some areas of the Soviet Union.

The following incidents were mentioned:

\section{KAZAKHSTAN}

The following people were arrested in Aulie-Ata city between 11-16 February:

1) the woman at the market with boiled human's parts. In the conclusion of medico-legal investigation parts of body belonged to a 6-7 years old child;

2) the Kazak man with chopped and boiled parts of a child in Uzbek cemetery.

Moreover, there was discovered a 22 years old Kazak woman, cut into parts (meat at the hips and hands were absent) in snow near Uzbek cemetery.

Human's meat was brought as a parcel to Shekenov who was in the prison of Karkaralinsk.

Mr.S... was keeping corpse of an unknown woman in his flat in Karkaralinsk city.

Investigation is conducted.

\section{NORTH AREA}

There was discovered killed prisoner Ivanov who was in convinct-labour colony in Pleseck region. Corpse does not have soft part of bodies, heart, liver, lungs were fried and eaten.

Some parts of meat was found in a raw state. Investigation is conducted.

19 people were arrested.

WPCA - Workers' and Peasants' Central Administration

USPA - United State Political Administration

Information above does not only show faith of individual person, it is a reflection of severities of the whole nation. Here is the numbers of the Kazakh tragedy:

Table 1. Quantity of Kazakhs in 1930-1933

\begin{tabular}{llc}
\hline & Years & Quantity of Kazakhs \\
\hline 1 & 1930 & 5873000 \\
2 & 1931 & 5114000 \\
3 & 1932 & 3227000 \\
4 & 1933 & 2493500
\end{tabular}

Note. From the data of the Moscow archive, 1937 (Omarbek, 2012).

As we see from the table above, the number of Kazakhs in 1931 was 5 million 873 thousand people, in 1933 - 2 million 493 thousand. During several years 3 million of Kazakhs just disappeared. What happened to them? It is 
still an important question of the Kazakh history and Kazakh faith which cannot restore its value. Truth of hunger has already discovered the nation's tragedy completely. In this way the problem should be noted.

\subsection{Historical Truth}

6 million of Jewish people died from fascism during 1939-1945; this story was announced as genocide by Nurnberg court and called Holocaust.

Because of consequences of the Soviet Union artificial hunger 3 million 941 thousand of Ukrainians died during 1932-1939. Order of appellate court of Kiev city announced "I. V. Stalin is guilty of organization of the genocide" in 2010, and this distress is called Holodomor.

The Kazakh nation lost its 3 million people because of consequences of the Soviet genocide during 1919-1922 and 1932-1933. However, terror of Kazakh nation still has not been examined and the black story of great calamity of our nation is not discussed. The consequences of genocide of the Soviet Union influenced the dramatic decrease of the Kazakh population. Tragedy of hunger is investigated in its level, but there is one of the most important problems in the Kazakh history which still cannot find its solution.

Sarah Cameron, Professor of the University of Maryland in the USA, said in the interview to the "Kazakh adebiyeti" newspaper: Hunger during 1930-33 was a terror for the whole society in Kazakhstan. However, countries outside do not know about this distress. Russia and Ukraine studied from scientific view the compulsory collectivization; they avoided the distress of difficult situation of hunger. Scientific works and monographs devoted to hunger and genocide do not speak about hunger in the Kazakh steppe, even if they mention information about it, it is just a little (Asharshylyk zhane Batys Zertteushilery).

Hunger and exile, censorship and repression were an enormous distress of history for the Kazakh nation. In this period the Kazakh intelligentsia Alashorda tried to use various methods and approaches. They tried to encourage the nation and worried about the future of the nation (Esenova, 2002). They tried to arouse nation's spirit. One of the most important people of Alashorda party is Jusupbek Aimautuly. He is a writer, publicist, founder of Kazakh psychology, critic and political figure. He was the first person who translated stories of American literature, exactly Jack London into the Kazakh language. He introduced classical masterpieces of Jack London, Rabindranath Tagore, Conrad Bercovici, Guy de Maupassant, Shakespeare, Gorkyi, Pushkin to Kazakh readers. Jusupbek Aimautuly translated Jack London's two stories "The Strength of the Strong", "The Unparalleled Invasion". "The Unparalleled Invasion" was published in the magazine "Zhana mektep" № 4-5 in 1926, "The Strength of the Strong" was introduced in the magazine "Leninshil zhas" № 6-7 in 1925. Many of his works were named after Tanashbai, Kyzylbas, Zhik, but these two stories that were translated from Jack London were named after his own name "Jusupbek", "Jusupbek Aimautuly". In that time these translations were published, although he was announced as a nationalist and English spy, and he was arrested and shot in 1931 in Moscow. Therefore, his successful works from the both view meaningful and artistic were prohibited till 1988, when he was discharged. Translations were unknown until the collection of full works was not published in 2009. There are a lot of information about his wonderful works of translation, but because of censorship the translated texts were on the shelves of archive with dust but now these works are free and available for readers. Jusupbek saved requirements and rules of translations in his works and used his skills in a perfect way. Therefore, his translations of Jack London came to readers with new thoughts and valuable ideas.

\subsection{Censorship Trick}

As it was mentioned before, the political situation of the time and the Kazakh intelligentsia was under pressure. If you go to the right - you will be shot, if you go to the - you will be deported, if you go straight - repression, prison (Balgamis, 2000). In these difficult times, the Kazakh intelligentsia united the efforts of the Kazakh people looking for new ways to awaken the spirit. A new way was translation with open truth to the people. If you will take any world classic translation of Alashorda people, every of them were with a spirit of Alash (Rottier, 2005).

According to the results of the research, the translations of Aimautuly adhere to the three basic principles:

1. The writing should be about people.

2. The work should contain social, cultural and spiritual values of the people.

3. The work should awake the spirit of the people, should be encouraging to fight for the aspirations for a better life.

Aimautuly's translations from J. London, R. Tagor, K. Berkovici, F. Dushen, Maupassant translations of a combination of political ideas would protect the interests of the population works. 
Having used the content analysis method, the word meaning in the works of 10 quantitative indicators were defined in the works "The Strength of the Strong" by Jack London, and "Kushtilerdin kushi" (translation) by Jusupbek Aimautuly. In general, we can say that Aimautuly used alternative way of translation. However, during the study difference and fluctuation of meaning was a subject of a special attention. The content analysis showed that Jack London used some words about 100 times, Jusupbek Aimautuly used only 30 times. It means that the interpreter used alternative words in the context according to his interpretation. At the same time, depending on the application and the number of words we can see the focus on the ideas of the authors.

Table 2. Numerical indication of original and translated text

\begin{tabular}{lcc}
\hline Words used in the works & $\begin{array}{c}\text { Numerical indication of words } \\
\text { used in J. London's works }\end{array}$ & $\begin{array}{c}\text { Numerical indications of words } \\
\text { used in Aimautuly's works }\end{array}$ \\
\hline Law //заң & 10 & 8 \\
Men//people//crowd & $68-7-1$ & $38-40$ \\
Ел//жұрт//халық & 16 & 16 \\
Council//кеңес & $9-1$ & 3 \\
Afraid of//wind & & \\
Қорку, қорқыныш & 22 & 0 \\
Tribe//тайпа & 104 & 39 \\
Wе//Біз & 15 & 10 \\
Ноuse//үй & 5 & 15 \\
Place //ground//Жер & 6 & 10 \\
Нunger//starvation/ашаршылық & 4 & 5 \\
King//Патша & $\mathbf{2 6 8}$ & $\mathbf{1 8 4}$ \\
\hline Total & & \\
\hline
\end{tabular}

While reading Jack London's and Jusupbek Aimautuly's works at first we cannot notice the difference. However, the meaning of each word and the subject line, compared with Aimautuly concentrate on some specific issues, and is determined by the description.

For example:

1. Aimautuly in his "The Strength of the Strong" translation did not use the word "tribe". Well, in Jack London's original version this word was used for 22 times. Why? Because, Jack London described real live of Indians who lived in tribal level, but Aimautuly was speaking about Indians parables to Kazakhs. But Kazakhs are not tribes; they are millions of people, with history and language, mentality and religion, with deep roots in the country .For this reason, Aimautuly who cover the translation of the name of the Indians in the illustration intends to describe the suffering of the Kazakh people of to be proved.

2. In Aimautuly's translation the word "Law" is less used than in Jack London's one. The main reason for this is the fact that the total population of the Kazakh was nomads before, therefore for the Kazakh people the word "law" would not have such a power like in America.

If London emphasized the importance of law, Aimautuly withdrew it from his translation. It is necessary to take into account the differences between the mentalities of the two countries. If you say to the citizen of America that he violates the law, he would afraid of it. But, for the life of the Kazakh steppe one should be literate. Moreover, Kazakh people learned to live according to the steppe rules. Common people did not understand what the power of law was and how to use it.

Another issue is that Aimautuly was shot in Butirka prison in Moscow on April 21, 1930. The accusation against him stated the following: "Jusupbek Aimautuly was a British spy and he did not give his cattle to the population who suffered from hunger". However, it has a special place in the Kazakh literature, forensic scientist who took part in the meetings of Aimautuly Beysenbay Kenzhebayev says: in 1921-1922 in some parts of Kazakhstan Kostanay, Torgay, Aktobe regions there was famine. In other provinces, everyone gathered independently aid for 
person in need. So, in Semei, Pavlodar regions Jusupbek gathered aid. Received help (cattle, grain) he distributed to the people. After it there was a criminal proceeding...

Court lasts for three days. On the third day Jusupbek said his last wish. He had written it before and recited it. All people in the hall were grateful. Jusupbek's last word was formed on the basis of the law of the Kazakh people and all traditions. He said: "Since ancient times the Kazakh people give loans, take loans back, give cattle and take it back. And nobody takes from each other any protocol, they do everything orally. This has become quite a habit. While distributing my help to people in need, I had all these habit in my mind. I followed this law. I didn't not take any paper from anyone, from nobody I helped. It was even inconvenient to ask for a paper from man who is dying from hunger. So, Jusupbek said to his defense" (Kenzhebayev, 1989).

The life of Aimautuly ends by being shot for not taking papers. Aimautuly proved that for the Kazakh people receipt, paper is not so important than moral principles are not the surface of the paper, the paper has proven to live longer than the law. Maybe it is the reason of a rare usage of the word "law" in Aimautuly's translations.

3. Another example of this is the word hunger/famine. The word "hunger" is used in Jack London's composition only 6 times, in Aimautuly's translation - 10 times. How often was the usage of the word famine in the translation of the work in the second language? Why Aimautuly used the word famine more than it was in the original text. It is felt that in Aimautuly's translation he described not Indian famine, he described the famine in Kazakh steppe. Maybe Indians had the famine too, but in the translation of Aimautuly there was a picture of the Kazakh tragedy. If Jack London wrote that Indians had famine, Indians were hungry, Aimautuly wrote about the reason of the famine. He thought that was the fault of the government. When talking about famine, Aimautuly described it with a special emphasis on the word. Aimautuly translation of the incidence of hunger as a result of the famine that killed people party, said changes in the country's human nature illustrations. Therefore, in Aimautuly's translation the word famine repeated for many times.

4. The word "Afraid of" we meet in Jack London's text in the English language 10 times; Aimautuly used it only 3 times. It proves that every interpreter is responsible for each word. By using this word less as it possible, Aimautuly shows that the Kazakh people had not sense of worry.

Of course, all of the political and social situation in the society can't be achieved through the translation of the work of art. Because there are requirements of translation. However, the translation of Aimautov's works with his own ideas does not lose anything to create a great work.

The most important thing is that he didn't want to abuse the original author's texts. In addition, his work was about the problem of people, and it was a new thing to the Kazakh steppe.

\subsection{The Security of the Nation}

The colonial policy of national identity of Russia aimed at weakening of the Kazakh language, religion, literature, and culture, being dangerous to the nation. First, there was the revocation of the Kazakh language into Cyrillic alphabet, and Tatar mullahs were sent to Kazakhstan with a special mission to baptize the Kazakh steppe. The secular intelligentsia of the nation "enemies of the people" were deported or executed. As the evidence here are the words of Stalin in 1937: "We will kill not only all the enemies, but also their families." (Mlechin, 2005).

During the Kazakh history, when the political and social situation was under the pressure Jusupbek Aimautuly translates J. London's another story into Kazakh "The Unparalleled Invasion". It is about the army that has millions of people and can destroy all the countries. The main idea is that the strength not in the great number of army, but in the country's science. Paying special attention to this, Aimautuly, said that in the twenties century we must not be proud of power of our army, it is time of power of knowledge and science. Aimautuly stated that wining a country through killing common people is the violence. On this example, he wanted to say that notwithstanding the fact that there were millions of people with a huge army, China was destroyed, and he draws attention why Kazakhstan couldn't resist Russia. "What is the criticism of the twentieth century?" - he answers to the question. Jusupbek Aimautuly hinted that the Kazakh nation have no power with their sword on their hand before the armed Russia. If a Kazakh wants to remain a Kazakh he needs to focus on saving national traditions and customs, language and mentality and turn attention to the science. Being against the imperialism he came to conclusion that the spirit of the people is essential to overcome it, there should be love for the nation. In 1928 Aimautuly published his article "Ultty suyu" in the journal Abay, 2-nd edition. In this article he says: "The nation I love and a lot of citizens who serve the people strong, talented, educated people,. Give respect to nationality, caring citizens of the country lags behind. Take for example Germany, Japan, England, Turkey, their children grow loving their nation. Becoming adults they spent their power to their nation. A country needs each 
of them..."

Aimautuly explained that being nationalist is not hating other, it is loving your own nation. Aimautuly got rid of the flock, for the survival of the Kazakh nation as every generation of young people to the infinite love of his country and not in the formal sense of patriotism science knowledge must be able to be inferior to the other countries. Kazakh's freedom, science and knowledge is what we can see in Aimautuly's ideas as a writer, wise politician. Entering the beginning of the 21 century today we are able to see what has become a tremendous force in the 20 century.

Taking China as an example that traditionally considers power as an important element, he talks about the terms in order the Kazakh land could have its place in the world.

Aimautuly in his own translation says: "The Chinese people are not bad. They are hard-working assiduous people that love piece. They consider that war is unpleasant, it takes place because of need." Aimautuly describes China with peaceful words, the heart of anyone who know the value of peace in the country illustrates that there is no fighting. Behind this idea he wanted to say that even if you don't attack anyone, you can be attacked. Because the Kazakhs were never envious on other countries and they never boasted on their wealth. However, it depends on other countries'bad intentions. He mentioned that there are others who are interested in your country and your place even if you don't think about it. Aimautuly describes how other countries sent planes and spread disease in China killing millions of people: Chinese army protected the borders of the whole China. China was ready to protect itself but it couldn't even hear the sound of the bullet and pistols. Chinese couldn't understand this secret. Suddenly one of the glass tubes from the plane in the sky fell destroying everything. A garden owner when saw one of the tubes in the water that wasn't broken brought it to the office. When officer broke the bottle down, several mosquito flied out. That is all. One and a half months later the streets of China were full of rotting bodies of dead people. People who died in China in this short period were described in the literature as follows: "That was the huge campaign to China. Milliards of peoples were in trouble. Full of disease, having lost unity they had only strength to die. In 1976 in the autumn there was something like a hell in China. The virus was everywhere. There was no province where infection didn't appear. Hundreds of thousands of people were not buried. Millions of people were dying every day... So, China was destroyed this way". It is the picture of genocide with millions of died people, ordinary people who died as a result of the disease. Aimautuly illustrated this situation of people who suffered as a result of political games with great enthusiasm. It was close to him. The Kazakh people also faced such a tragedy because of starvation as a result of hunger, disease, genocide, the streets were also full with died people. A Kazakh reader who knows the history of Kazakhstan, the ideas of Alash, the consequences of the famine that was called "Great Famine" would feel and understand it.

Thus another question which Aimautuly shows: "When there was a chaos on the front, they came to the the threshold of Turkestan where German and Australian soldiers were..." Even in the original version of the text there mentioned that the borders of Turkestan should be the borders of Turkestan autonomy established in 1917. Turkestan autonomy was established with the purpose the people of Turkestan could have their own government. Aimautuly could also select the information that was relevant to Turkistan autonomy from the American literature. But won't it be food for thought if someday the Kazakh people would lose their history because of the censorship in the translations of the Kazakh literature there will be mentioned European soldiers standing on the region which borders with China?

\subsection{Bibliography as a Mirror of Reality}

Another interesting thing is that there are similarities in Jusupbek Aimautuly's and Jack London's lives. They are not just the writers of the two countries who promoted the common values of all humanity with the purpose of sharing ideas and wishes of individuals. Their unique writing styles and features are also compatible with each other,

Jack London from his early childhood had to work and his all the difficulties of life. The reason why he earned money was that he wanted to protect interests of the weak. And like a copy of his own life Aimautuly writes the novel "Kartkozha". The novel reflects the young child's life, compassion for the weak formed on difficulties Aimautov faced in his life. Kartkozha boy in the novel was like a prototype of young child Jusupbek Aimautuly. Two years old aimed to serve the same dream. The great writer London describes face of the people's psychological feeling in his works, either did Aimautuly. It is impossible to describe their love and respect for writing and literature. Jack London's had a short life but worked for 17-18 hours a day, Aimautuly had to move from one place to another under the pressure of censorship, established the foundation of the Kazakh prose and the Kazakh psychology science (Mazhitayeva et al., 2015). In order to show their love to literature we took 
examples of their works.

\section{Conclusion}

At the beginning of the twentieth century American literature, Jack London's stories were recognized by the first translations for the Kazakh reader. However, these translations are not just a piece of art, they are a mirror of the spirit of the Kazakh nation. London's translations about Indian tribes which come over the ocean not only tell the story but awaked the Kazakh people and generated a sense of freedom. There were some reasons to choose "The Strength of the Strong" and "The Unparalleled Invasion".

1. Jack London was the author whose works were translated into Russian. His communist views were consistent with the ideology of the Russian Empire.

2. It was easier and less dangerous to translate J. London's works than to publish Aimautuly's own because of the censorship.

3. The most important thing was that Aimautuly's ideas were reflected in London's compositions. Aimautuly saw in London's works the Kazakh society's most difficult issues and solving of these problems. He tried to show the similarity of the Indians' and the Kazakh people's destiny.

Aimautuly's aim was to work to the future of the Kazakh nation. The main dream of Alash was the independence and development of the Kazakh nation. With this purpose they used all opportunities to save the Kazakh language and religion, history and customs of the soul. One of them was to reflect, show the nation's problems through the translations.

The works of Jack London had effect on the Kazakh spirit, however, the author doesn't know about contribution to the promotion of the idea of the Kazakh people's independence. J. London's ideas of the human and moral principles of equality took place in the heart of the Kazakh readers. Of course, it should be mentioned that it was done through the translations by Aimautuly. Thus, Aimautuly translations were affected by the following problems:

1. Aimautuly by translating Jack London's "The Strength of the Strong" wanted to draw attention of the Kazakh people that "a state's power in its unity". This work is still topical for the country didn't lose its relevance today.

2. Aimautuly through translations try to show the topics which were prohibited by the censorship. Aimautuly through translation of the London's stories about the fate of the Indians tries to reflect the destiny of the Kazakh people which faced the violence of the policy of Russia, the issues of the national security and consequences of the famine.

3. Jusupbek Aimautuly by translating London's "The Unparalleled Invasion" explained to the Kazakh people that the twentieth century is the century of science and education.

As an example he mentions China that believes in the power of the army, not in science. By criticizing imperialism, actions of powerful countries, he underlines the importance of knowledge

Thus, the American literature being on the other side of the ocean had its impact on the Kazakh people, through the strong understanding of the country and strengthening of the unity of the nation.

It is also necessary to note the contribution and the breakthrough in the implementation of human thought of one of members of Alashorda, the Kazakh classic writer, the first translator of the American literary classic works Jusupbek Aimautuly. Jusupbek Aimautuly was the master of writing whose great translations were done in compliance with the terms, and who wanted to reflect his ideas to people which had a great importance for them. It was his wisdom, it was his personality.

\section{Acknowledgments}

I would like to express my deepest gratitude to Eurasian National University and the Ministry of Education and Science of the Republic of Kazakhstan for giving me scholarship to obtain PhD degree. Also, I thank to my colleagues and professor who opened me the new ideas and shared with new knowledge.

\section{References}

Asharshylyk zhane Batys Zertteushileri (2012). Kazakh adebiyeti, 23, 3291.

Balgamis, D. (2000). The Origins and Development of Kazakh Intellectual Elites in the Pre-Revolutionary Period 1920 (Unpublished doctoral dissertation). University of Wisconsin, USA.

Esenova, S. (2002). Soviet Nationality, Identity, and Ethnicity in Central Asia: Historic Narratives and Kazakh 
Ethnic Identity. Journal of Muslim Minority Affairs, 22(1), 11-38.

J. Aimautuly's Collection of Works. (2013). Almaty: El-Shezhire.

Jusupbek Aimautov. (2014). Anyz Adam, 17, 101.

Kendirbaeva, G. (1999). 'We are Children of Alash...' The Kazakh Intelligentsia at the Beginning of the 20th Century in Search of National Identity and Prospects of the Cultural Survival of the Kazakh People. Central Asian Survey, 18(1), 5-36.

Kenzhebayev, B. (1989). Telegei teniz. Estelik. Leninshil zhas, 1, 3-5.

Koigeldiyev, M., \& Omarbekov, T. (1993). Tarikh gylymy ne deidi? Almaty: Ana Tili.

Mazhitayeva, Sh., Rapisheva, Zh., Kagazbayev, Zh., Toleubayeva, K., Zhumagulov, A., Zhumagulov, S., \& Smagulova, N. (2015). The Creative Activity of National Intelligencia in the Creation of Kazakh Terminology. Asian Social Science, 11, 19.

Mlechin, L. (2005). KGB. Predsedateli organov gosbezopasnosti. Rassekrechennye sudby. Moskva.

Omarbek, T. (2012, May 31). Asharshylyk khikayati tolyk ashyldy ma? Zan Newspaper.

Rottier, P. (2005). Creating the Kazak Nation: The Intelligentsia's Quest for Acceptance in the Russian Empire, 1905-1920 (Unpublished doctoral dissertation). University of Wisconsin, USA.

\section{Copyrights}

Copyright for this article is retained by the author (s), with first publication rights granted to the journal.

This is an open-access article distributed under the terms and conditions of the Creative Commons Attribution license (http://creativecommons.org/licenses/by/3.0/). 